DOI: https://doi.org/10.47405/mjssh.v5i5.401

\begin{tabular}{|c|c|}
\hline 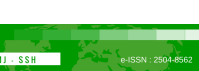 & Malaysian Journal of Social Sciences and Humanities (MJSSH) \\
\hline Malaysian Journal of & Volume 5, Issue 5, May 2020 \\
\hline $\begin{array}{l}\text { Humantitus } \\
\text { (MJ - SSH) }\end{array}$ & e-ISSN : 2504-8562 \\
\hline & $\begin{array}{l}\text { Journal home page: } \\
\text { www.msocialsciences.com }\end{array}$ \\
\hline
\end{tabular}

\title{
The Roles of Non-Governmental Organisations (NGOs) in Assisting Refugees: From Malaysia Context
}

\author{
Hemamalani Kunapalan', Norafidah Binti Ismail1, Aminurraasyid Bin Yatiban1 \\ ${ }^{1}$ School of International Studies, College of Law, Government and International Studies, Universiti Utara Malaysia \\ (UUM)
}

Correspondence: Hemamalani Kunapalan (hemamalani@msu.edu.my)

\begin{abstract}
This conceptual paper is to determine the contribution of Non-Governmental Organisations (NGO's) in Malaysia towards refugees in terms assisting to provide basic accommodation. The main questions in this study is how NGO assisting refugees to access basic facilities in Malaysia. This study also will address the responses and challenges faced by refugees to access basic necessities. NGO's in Malaysia has various responsibilities in assisting refugees especially issues related to the serious illness and place for settlements. United Nations High Commissioner for Refugees (UNHCR) role in leading NGO's in Malaysia in providing international protection and long-term solutions with cooperation from government policies will be discussed. Execution of policies and programs has many challenges and limitations which will be discussed in this conceptual paper.
\end{abstract}

Keywords: refugees, non-governmental organisations, government policies, humanitarian efforts

\section{Introduction}

Refugees in Malaysia had faced various obstacles before they reach to this state. Most of them are often in vulnerable situation when fleeing from war or prosecution. Moreover, they are in intolerable situation where the basic rights could be in danger, for instance security, accommodation, food supply and other basic necessity like clothes. Especially, refugees including women and children are far more vulnerable to handle and basic needs should be immediately supplied whenever they are in our border.

Apparently, there are several local based NGOs working in Malaysia on refuges and asylum-seekers. The NGOs working to the level best to get access of refugees to assist them and provides basic needs. Even though, the integration between refugees and migrants were not in the top notch with NGOs, they are need to access with effective way in order to avoid them isolated in particular placement. The role of NGOs in this situation has become extremely important especially in providing services for those who had reached in the country. Without any serious plan collecting and distribution of supplies and other facilities, a great number of poor refugees could be mentally and physically traumatized.

In this paper, the importance of NGOs role will be discussed precisely to expose cohesive understanding of the responsibility. Other than that, brief previous studies will be looked back on the contribution of ideas from previous scholars and the effectiveness of the strategies proposed. Lastly, in this paper also will recognize the challenges and limitation that NGOs face when they were in the field. 
The proposed ideas should be contributed for the goodness for both NGOs and refugees or asylumseekers so that NGOs could freely execute the responsibilities to guide these guests into our place.

\section{Literature Review}

The role of NGOs has become increasingly important especially in providing services for those who are reached Malaysia. The role of the authority does not only stop at the checkpoints across the borders either. There are gigantic of issues of refugees or asylum-seekers faced once they in Malaysia. However, while governmental services can offer much but there are significant gaps from the offer they could give. Hence, the role of NGOs has huge responsible in guiding the refugees. In this part, there are various previous studies can be exposed in regarding of the precious role of the NGOs to be the messenger and guardians for refugees.

According to UNCHR (2020), there are some 178,990 refugees and asylum-seekers legally registered with UNCHR in Malaysia. There are approximately, 154,080 from Myanmar which includes some 101,010 Rohingyas, 22,810 China and 30,250 others from Myanmar. Other than that, there about 24,900 refugees from other countries encompasses 6,660 Pakistanis, 3,680 Yemenis, 3,290 Somalis, 3,290 Iraqis, 790 Palestinians and from other countries as well. Overall, approximately $68 \%$ of men and women compromise about $32 \%$. Moreover, there are some 46,520 children below the age of 18 in the country. The number shows that, most of the refugees and asylum-seekers are mentally and physically vulnerable due to the abuse and harassments that they gone through.

H Lego (2012), emphasizes that, protection and assistance of refugee and asylum seekers in Malaysia is implemented through informal mechanisms. Those mechanisms were established by the UNHCR in cooperation with NGO and made possible through a state of omission justified on the grounds of the Malaysia state's irregular declaration of humanitarianism. Besides, in allowing certain exceptions for refugees, the Malaysia government is now no way accepting any of its sovereignty. Rather, it is declaring it. To be fair, humanitarian makes small inroads in the effort to offer much needed support to refugee. Moreover, the UNHCR's existence in Malaysia is justified, services-oriented NGOs are allowed to function, and Muslim refugees, especially are tolerated and sometimes even accepted into society.

Malaysia is not a signatory to the 1951 Convention Relating to the status of refugee 1967 protocol. It has no legal framework, guidelines or administrative procedures to address the right to seek asylum or to provide humanitarian assistance or protection of refugee. Moreover, he mentioned in his work that, asylum seekers and refugee are viewed as prohibited immigrants as per Malaysia Immigration laws. This means, the asylum seekers and refugees who illegally enter and stay and are subject to the threat of arrest, detention and deportation contrary to international law. People of concern and their children have no access to employment, education and health care which further isolate them (Munir-Asen, 2018).

On the basis of the comprehensive literature review the role of NGO in handling and assisting refugees less discussed in an open forum as it involves fewer known parties. Other than that, less debate reported involving the well-being of the refugees especially when Malaysia did not have any legal responsibility towards refugees (Nasir, Salleh \& Haque, 2019). However, in the ground of humanitarianism Malaysia had offered protection and assistance through informal mechanism with the cooperation from UNHCR (Kunapalan, Ismail \& Yatiban, 2016). Meanwhile, according to Human Rights Commission of Malaysia (SUHAKAM), 2019, these refugees easily targeted as a prey as they are still vulnerable to arrest, exploitation, domestic abuse and deportation even if they possess an UNHCR card. Hence, in order to protect the refugee's government policies and NGO have to cooperate in providing them enough security and protection. 


\section{Discussion}

There are several main roles that NGOs should practise and implement in order refugees and asylum seeker receives proper treatments. Firstly, fundamental relation and cooperation with government bodies and agencies should be improved among NGOs. This roundtable is vital in order to sit together and find appropriate measures and an idea which is aligned to the national policy. The government had publicly announced, (Kumar, 2015) the creation of temporary work permit to allow legally registered refugees to work in Malaysia. However, this initiative has yet to be successfully implemented as the lack of joint hands with various parties. Meanwhile, the plan to issue 10,000 work permits had been stranded as corruption activities intervention in the scheme (Cheung, 2012; Hoffstaeder, 2015; Needham, 2011). Hence, cooperation between NGOs and government agency enables them to have check and balance in every scheme implemented and the initiative can be reached to the needy.

Education for refugees and asylum seekers in Malaysia seems they are not allowed to have formal education similar to local citizen. Thus, UNHCR with the assistant from the NGOs and other corporate bodies align together to operate learning centres for the refugee's children (Lego, 2012). Hence, there are about 120 learning centres in Malaysia mostly situated in Klang Valley, Penang and Johore. Moreover, the teachers mostly among the refugee's community themselves, foreigners and locals who are voluntarily came forward to provide them knowledge (Jessica, 2017). So, the corporations from private and corporate agencies could enable them to raise enough funds as part of corporate social responsibility to the corporates. Basic knowledge and proper education according to age to the youngsters is vital in order to provide basic IQ and general knowledge to let them surviving in this country.

Moreover, learning centre needs fund to run for the refugees all over place where the refugees located. So, essential fund and monetary supply needed in order to set up learning centres (Kok, Low \& Lee, 2013). Other than that, NGOs need to prepare appropriate equipment's and tools for the learning centre. Hence, cooperation and collaboration with corporate bodies and government agencies are vital to promote education among refugees and asylum seekers (Low, Kok \& Lee, 2014). Basic knowledge about our country is a must so that are aware of our system and policies. Otherwise, they may breach the law and order in the country and so that our local citizen and the refugees themselves live in harmony. So, government allocation and aids might be not enough to bear the expenses for long period of time, for continues support may need extra aids for private sectors and other organization voluntary to run the cause (Yusoff, Nasir, Salleh, \& Mahbubul, 2019). Hence, proper knowledge sharing is necessary for refugees in order to strengthen social integration and language gaps among refugees and asylum seekers.

In addition, close and regular supervision of implementation of programs is necessary to increase the effectiveness of the adaptation. Hence, bilingual staffs in NGO itself will be an advantage for the learning centre to understand the refugees even better (Letchamanan, 2013). Thus, the volunteers who are willing to help would be able to implement programme according their needs. Most importantly within the community there will be isolation if they are only accessible in one particular place. So, NGOs may place them in group in different area within the local communities so that they could adapt and learn our culture and tradition of local citizens (WeiQian, 2019). Other than that, programme must encompass national studies and constitution in based level in order to give them opportunity to be one among local communities (Wake \& Cheung, 2016). Otherwise it may take more time and will be left behind to travel together as one among local communities.

Moreover, the on-going conflict and violence causes serious displacement that causes refugees to seek immediate protection in nearby countries. These cause serious distress and mental health problem among refugees (Shaw, Pillai \& Ward, 2019). Even though some country is not willing to accept them but some like country like us receives them for safety. Other than that, huge amount of families, women and children willing to undertook tough and dangerous journey across several countries (Ayadurai, 2011). Meanwhile they also exposed to danger when smuggler might exploit them. NGOs with collaboration between local and federal government should be always alert with facilities and accommodation for the refugees. So, the collaboration of government agency, NGOs and appropriate 
fund to support refugees to provide basic necessities, accommodation and basic knowledge is essential is a huge help for refugees to them rise from left behind (Kunapalan, Ismail \& Yatiban, 2016).

\section{Challenges of local based NGOs in handling refugee in Malaysia}

There are several challenges that NGOs going through to provide basic facilities towards refugees and asylum seekers. Firstly, there are lacks legislative or administrative provision to legally assisting refugees and asylum seekers in Malaysia (UNHCR, 2019). So, UNHCR and NGOs are organizing activities related on protecting in terms registration, documentation and accommodation as well. Hence, government agencies with UNHCR should be closely collaborated in order to provide essential protection and security to the refugees and asylum seeker until they remain confident to face any prosecution or obstacles in the future. Moreover, providing legal and physical protection could hinder threat of abuse and violence as a part of humanitarian support to the refugees and asylum seekers.

Other than that, education access to the refuges especially to their children should be precisely handled as this will determine refuges future and well-being. Education access had been provided with the collaboration with UNHCR and NGOs itself to the refugee's children and mostly organized by the refugee's communities itself (Patricia, 2015). However, these programs or projects only benefited $20 \%$ of refugee children. This number shows the needs of awareness and promotion among refugee in order to avoid the younger generation future from jeopardized. Hence, NGOs could enable to gain support from corporate bodies and donation to provide enough resources and hire qualified teachers so that to ensure refugees children have better life. Moreover, education policies for refugee's children in Malaysia should be implemented and formulated by UNHCR as the international organization which deals on refugees (Hema, 2013).

On the other hand, seeking medical assistant for the refugees had been a huge challenging task in both public and private hospitals. This issue occurs as the healthcare cost in increasingly high and issues in legal status of the refuges themselves. However, public hospitals are giving medical treatment for refugees with 50 per cent discount on registration and medical fees (Caitlin \& Tania, 2016). Nowadays situation gets tougher when healthcare expenses dramatically getting higher since 2015 . Thus, refugees with UNHCR official card may not find more trouble unlike those refugees who are registered but have not receive the UNHCR card. Hence, these refugees may face huge obstacle if they need immediate medical attention for serious health condition. So, this issue needs to be addressed as soon as possible to enable them to seek medical attention without any prior delay.

Lastly, refugees need sufficient fund to fulfil basic needs among themselves. One of the initiatives that we aware recently was employment programme for refugees which receives unsatisfactory results as less participation encountered in the programme. In addition, NGOs also having challenges and difficulties in organizing programs as they don't have enough fund and capacity. So, this is the time where private entities to come forward to support as a part of Corporate social responsibility. Moreover, support from private individual and potential donor need to be recognized to the work of NGOs involve in funding the refugees. Moreover, private sector and NGOs should have a platform so that they could create a network between NGOs, corporates and even donors from various entities. Hence, by creating such networks enables them to run assistance programmes for refugees in terms of healthcare, education, security and livelihood.

\section{Conclusion}

NGOs are playing vital role in protecting refugees in Malaysia. In other words, they are back bones to refugees in Malaysia. Much has been said and written about the role of NGOs with regard to refugees. Nowadays NGOs role in guiding refugees have become a new phenomenon and emerging as a preferred channel humanitarian cause to refugees. however, NGOs has been in the field long before than government agencies. There are several challenges facing by Malaysia's based NGOs in handling the refugee dilemma in Malaysia. Further mechanisms should be identifying in order to overcome the 
refugee's problems. NGOs working in the refugee field have always played a unique role immobilizing public opinion and prompting political support in defence of humanitarian and human rights principles in guaranteeing refugee protection.

Meanwhile, this study will show indication to rectify the weaknesses in assisting the refugees and will gain benefits to the NGO's by utilizing more resources. Moreover, government agency can be more cooperative with NGO's in providing humanitarian efforts through them so that those funds and resources is not mishandled or jeopardized. Hence, those challenges that had been mentioned can be easily rectified with proper planning and strategies. In addition, more studies will be done on the measures and new ideas to promote the well being of the refugees so that we try our best to not left them behind.

\section{References}

Ayadurai, S. (2011). Challenges faced by women refugees in initiating entrepreneurial ventures in a host country: Case study of UNHCR women refugees in Malaysia. Asian Journal of Business and Management Sciences, 1(3), 85-96.

Baylis, J., \& Smith, S. (2001). The globalization of world politics. Oxford: Oxford University Press

Cheung, S. (2012) 'Migration Control and the Solutions Impasse in South and Southeast Asia: Implications from the Rohingya Experience', Journal of Refugee Studies, 25(1).

Caitlin Wake \& Tania Cheung, (2016), Livelihood Strategies of Rohingya Refugees in Malaysia: "We want live in dignity "; Overseas Development Institute.

Hoffstaedter, G. (2015) 'Urban Refugees and UNHCR in Kuala Lumpur', in K. Koizumi and G. Hoffstaedter (eds) Urban Refugees: Challenges in Protection, Services and Policy. Abingdon: Routledge.

H Lego, J. (2012). Protecting and Assisting Refugees and Asylum-Seekers in Malaysia: The Role of the UNHCR, Informal Mechanisms, and the 'Humanitarian Exception'. Journal Of Political Science \& Sociology, (17), 75-99. Retrieved from http://koara.lib.keio.ac.jp/xoonips/

Human Rights Commission of Malaysia (SUHAKAM). (2009). Annual Report (Kuala Lumpur.

Jessica Rush (2017), Oxford graduate and legal intern at ACAA; Behind the numbers: the role of NGOs in the refugee crisis; http://blogs.lse.ac.uk/researchingsociology/2016/10/27/behind-thenumbers-the-role-of-ngos-in-the-refugee-crisis/ 1/3.

Kok, J. K., Low, S. K., \& Lee, W. Y. (2013). Dreams and participation in education: A narrative inquiries into the life experience of Myanmar refugees in Malaysia. Journal of Advanced Social Research, 3(2), 79-92.

Kumar, P. (2015) 'Malaysia Mulls Opening Jobs Sector for Rohingya Refugees', Malaysian Reserve, 18 November.

Kunapalan, H., Ismail, N., \& Yatiban, A. (2017). The Securitization of Refugees; the Challenges of UNHCR and NGOS in Protecting and Assisting Refugee in Malaysia, from http://internationaljournalcorner.com/index.php/theijhss/article/view/125735/0

Letchamanan, H. (2013). Myanmar's Rohingya refugees in Malaysia: Education and the way forward. Journal of International and Comparative Education (JICE), 86-97.

Lego, J. B. H. (2012). Protecting and Assisting Refugees and Asylum-Seekers in Malaysia: The Role of the UNHCR, Informal Mechanisms, and the 'Humanitarian Exception'. Journal of Political Science \& Sociology, (17).

Low, S. K., Kok, J. K., \& Lee, W. Y. (2014). Perceived discrimination and psychological distress of Myanmar refugees in Malaysia. International Journal of Social Science and Humanity, 4(3), 201.

Loescher, G., \& Milner, J. (2005). The significance of protracted refugee situations. The Adelphi Papers, 45(375), 7-12. http://dx.doi.org/10.1080/05679320500212098

Munir-Asen, K. (2018). (Re)negotiating refugee protection in Malaysia. German: German development institute.

Nasir, S. M. B. Y. @ M., Salleh, M. A., \& Haque, M. M. (2019). Malaysian Policy towards Refugees and Asylum Seekers: A Case Study of Rohingya Refugees. International Journal of Academic Research in Progressive Education and Development, 8(3), 110-117 
DOI: https://doi.org/10.47405/mjssh.v5i5.401

Needham, K. (2011) 'Malaysia's Work Rights for Refugees', Sydney Morning Herald, 29 July.

Nordin, R., Whelan, J., Aziz, S., Rajagopal, M., Mansor, I., Touma, M., \& Ralton, M. (2020). Unaccompanied \& Denied: Regional Legal Framework for Unaccompanied Minors Asylum Seekers (UMAS). $\quad$ Retrieved 31 March 2020, from http://ilrev.ui.ac.id/index.php/home/article/view/186

Patricia Casandra PAPUC (2015), UNHCR and Non-Governmental Organizations Role and Their Joint Efforts in Tackling the European Refugee Crisis from Its Inception until Present Times; Challenges of the Knowledge Society. Public Law.

Pang, V., Teng Ling, M., \& Tibok, R. (2019). Achievement of children in an alternative education programme for refugee, stateless and undocumented children in sabah, malaysia. Journal of Nusantara Studies (JONUS), 4(2), 335-361. doi: 10.24200/jonus. vol4iss2pp335-361.

Refugees, U. (2020). Figures at a Glance in Malaysia. Retrieved 20 March 2020, from https://www.unhcr.org/en-my/figures-at-a-glance-in-malaysia.html

Shaw, S. A., Pillai, V., \& Ward, K. P. (2019). Assessing mental health and service needs among refugees in Malaysia. International Journal of Social Welfare, 28(1), 44-52.

Wake, C., \& Cheung, T. (2016). Livelihood strategies of Rohingya refugees in Malaysia:'We want to live in dignity'.

WeiQian, K. (2019). Refugee Education In Another Perspective: The Current State In Malaysia And Its Way Forward. The bulletin of the Graduate School, Soka University, (40), 153-167.

Yusoff, S. M. B., Nasir, M., Salleh, M. A., \& Mahbubul, M. (2019). Malaysian Policy towards Refugees and Asylum Seekers: A Case Study of Rohingya Refugees. 8(3), 110-117. 